\title{
Macroscopic palygorskite from Lisbom Volcanic Complex
}

\author{
MERCEDES SUÁREZ ${ }^{*} *$ and EMILIA GARCÍA ROMERO²
}

\author{
${ }^{1}$ Dpto. de Geología, Area de Cristalografía y Mineralogía, Universidad de Salamanca, \\ Plaza de la Merced s/n, 37008 Salamanca, Spain \\ *Corresponding author, e-mail: msuarez@usal.es \\ ${ }^{2}$ Dpto. de Cristalografía y Mineralogía, Facultad de C. C. Geológicas, Universidad \\ Complutense, Madrid, Spain
}

\begin{abstract}
The palygorskite of the Volcanic Complex near of Lisbom (Portugal) is particular both in the size of the fibres and in chemical composition. It appears as veins of very pure mineral. From hand specimen and optical observations it can be described as a macroscopic palygorskite. The crystals are large with exfoliation traces of several hundred microns to few millimetres in length. In thin section, this palygorskite is colourless, translucent, negative biaxial, with positive elongation and parallel extinction. The optically homogeneous fibres and laths are shown by the selected area electron diffraction to be composed of aggregates of much thinner fibres rotated differently around the c crystal axis which represents their common elongation direction. The chemical formula obtained by the X-ray EDS is $\mathrm{Si}_{8.02} \mathrm{O}_{20}\left(\mathrm{Al}_{1.91} \mathrm{Fe}_{0.04} \mathrm{Mg}_{2.01}\right)(\mathrm{OH})_{2}\left(\mathrm{OH}_{2}\right)_{4} \mathrm{Ca}_{0.01} \mathrm{Na}_{0.07} 4\left(\mathrm{H}_{2} \mathrm{O}\right)$ very close to the ideal formula of a pure $\mathrm{Mg}$-Al palygorskite, with almost no octahedral Fe, and no Al in tetrahedral sites. The cell parameters are $a_{0}$ or $a_{0} \sin \beta=12.64 \AA$, $b_{0}=17.84 \AA$ and $c_{0}=5.3 \AA$.
\end{abstract}

Key-words: palygorskite, macrocrystalline palygorskite, electron microscopy, powder diffraction, FTIR spectroscopy.

\section{Introduction}

Palygorskite is a clay mineral that together with sepiolite forms the group of fibrous clay minerals. Bradley (1940) proposed the structure of palygorskite from a trioctahedral model although he described the existence of a dioctahedral term with octahedral holes when he pointed out that in the section (010) palygorskite is similar to montorillonite with a layer of water. Christ et al. (1969) and Chisholm (1990) proposed the existence of two forms, an orthorhombic and a monoclinic, but according to Chisholm (1992) both polymorphs appear in mixture in most of the natural samples. Different authors over the last few decades revisited the structure proposed by Bradley (1940) and no differences with this model have been found. The most recent papers which study the structure of palygorskite by high-resolution synchrotron radiation confirm the Bradley's structural model (Artioli et al., 1994 and Chiari et al., 2003), and Giustetto \& Chiari (2004), by neutron powder diffraction, found a different arrangement in the zeolitic water for monoclinic and orthorhombic forms. Galán \& Carretero (1999) affirmed that palygorskite contains mainly $\mathrm{Mg}, \mathrm{Al}$ and $\mathrm{Fe}$ with a $\mathrm{R}^{2+} / \mathrm{R}^{3+}$ ratio close to 1 , and also that the corresponding theoretical structural formula is $\mathrm{Si}_{8} \mathrm{O}_{20} \mathrm{Al}_{2} \mathrm{Mg}_{2}$ $(\mathrm{OH})_{2}\left(\mathrm{OH}_{2}\right) 4 \cdot 4 \mathrm{H}_{2} \mathrm{O}$. García-Romero et al. (2004) reported a very rich magnesium palygorskite which they compared with other palygorskites and with the biblio- graphic data, and verified that in all samples the $\mathrm{Al}$ content is less than $\mathrm{Mg}$ content in the octahedral layer, although the rate $\mathrm{R}^{3+}: \mathrm{Mg}$ is close to 1 due to the presence of $\mathrm{Fe}^{3+}$ in most of the samples.

The habit of palygorskite, as a consequence of its structure, is fibrous and the $\mathrm{c}$ axis (or a for some authors) is parallel to the fibre. The sizes described in literature are between $100 \AA-4 \mu \mathrm{m}$ in length with sections of about $100-300 \AA x$ 50-100 А (Jones \& Galan, 1988), but the most frequent length measured by transmission electron microscopy are less than $1 \mu \mathrm{m}$. Rautureau et al. (1979) studied palygorskites from different localities by TEM and grouped them according to length: "very long fibres" of several micrometres, "medium length" of approximately one micron, and "short fibres", a fraction of a micrometre.

\section{Materials and methods}

The palygorskite here studied proceeds from the Lisbom Volcanic Complex (LVC) and it appears as veins of very pure mineral. The presence of palygorskite in LVC as a product of alteration or weathering of basalt and other volcanic rocks has been known for forty years (Galopim de Carvalho et al., 1970, Prudencio et al., 1993 and 1995). In oldest references to the palygorskite from LVC, this mineral was considered as an amphibole (Choffat, 1950). 
Mineralogical characterization was performed by X-ray diffraction (XRD) using a Siemens D 500 XRD diffractometer with $\mathrm{Cu} \mathrm{K} \alpha$ radiation and a graphite monochromator. The samples used were random-powder specimens. Powders were scanned from $2-65^{\circ} 2 \theta$ at a $0.02^{\circ} 2 \theta / 3$ sec scan speed.

Particle morphology and textural relationships were established by scanning electron microscopy (SEM) and transmission electron microscopy (TEM). SEM observations were performed using a JEOL JSM 6400 microscope, operating at $20 \mathrm{kV}$ and equipped with a Link System energy dispersive X-ray microanaliser (EDX). Prior to SEM examination, freshly fractured surfaces of representative samples were air-dried and coated with Au under vacuum. TEM observations were performed by depositing a drop of diluted suspension on a microscopic grid with collodion.

Chemical composition was obtained by analytical electron microscopy (AEM) with TEM, in samples of great purity, using a JEOL 2000 FX microscope equipped with a double-tilt sample holder (up to a maximum of $\pm 45^{\circ}$ ) at an acceleration voltage of $200 \mathrm{kV}$, with $0.5 \mathrm{~mm}$ zeta-axis displacement and $0.31 \mathrm{~nm}$ point-to-point resolution. The microscope incorporates an OXFORD ISIS energy dispersive $\mathrm{X}$-ray spectrometer $(136 \mathrm{eV}$ resolution at $5.39 \mathrm{keV})$ and has its own software for quantitative analysis. Four reference samples, widely studied and reported in the literature, were used to test the validity of the K-factors employed in the calculations for the transformation of intensity ratios to concentration. The reference samples from Attapulgus (Georgia, U.S.A.), Bercimuel (Segovia, Spain), Yucatán (México) and Torrejón el Rubio (Cáceres, Spain) were analyzed under the same conditions employed for LVC palygorskite. Structural formulae for palygorskites have been calculated from the ideal structure, normalised to 42 negative charges. Oxygen was not measured quantitatively. All the Fe present was considered as $\mathrm{Fe}^{3+}$, but the possible existence of $\mathrm{Fe}^{2+}$ should be taken into account.

The Fourier transformed infrared spectrometry (FTIR) was recorded in the 4000 to $400 \mathrm{~cm}^{-1}$ ranges on a BRUKER EQUINOX 55 spectrometer. The samples were prepared using the $\mathrm{KBr}$ pellet technique.

\section{Results and discussion}

\section{Textural and microtextural features}

The palygorskite from LVC exhibits a laminar texture due to its origin as vein filling. Its colour is nacreous white and the thickness of the plates is between $1 \mathrm{~mm}$ to $1 \mathrm{~cm}$. On the surface of these plates long parallel lines can be seen due to the fibrous morphology of the mineral. On the edge of the plates small fibres can be seen with the naked eye. When the sample is studied by binocular lens, the palygorskite is similar in appearance. The fibres that can be observed are arranged parallel to one another and they seem to form a laminar crystal with exfoliation traces (Fig. 1a and 1b). At this scale the fibres are translucent, whitish in colour and they form thin plates. On the edge of the plates the fibres can be observed and although they cannot be measured precisely, it is possible to say that the length of the fibres is at least several millimetres. Due to the arrangement of the fibres forming plates, palygorskite can be exfoliated so thinly that it is transparent to light, and it can be examined in an optical microscope with the fibres placed parallel to the stage (Fig. 2a and 2b). In this way, accurate optical parameters such as birefringence and refractive indices cannot be determined because the thickness of the plates is not homogeneous and is difficult to measure. However, the transparency, colourlessness and anisotropic behaviour can be described.
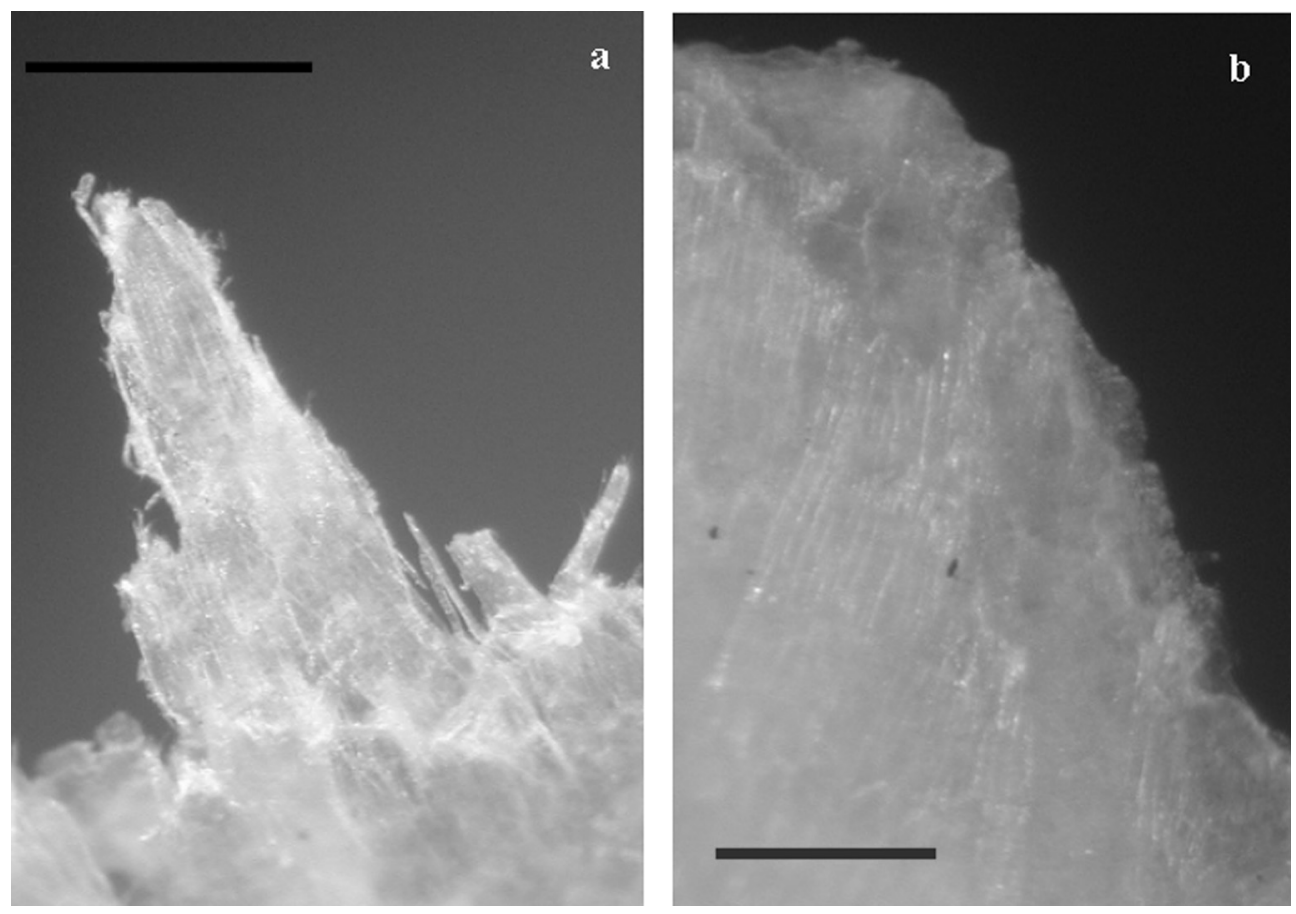

Fig. 1. Appearance of palygorskite from LVC under the binocular lens. Scales denote $1 \mathrm{~mm}$. 
Fig. 2. Microscopic images on the edge of a plate of palygorskite. a) Normal view. b) With crossed polars. Scale denotes $0.1 \mathrm{~mm}$.

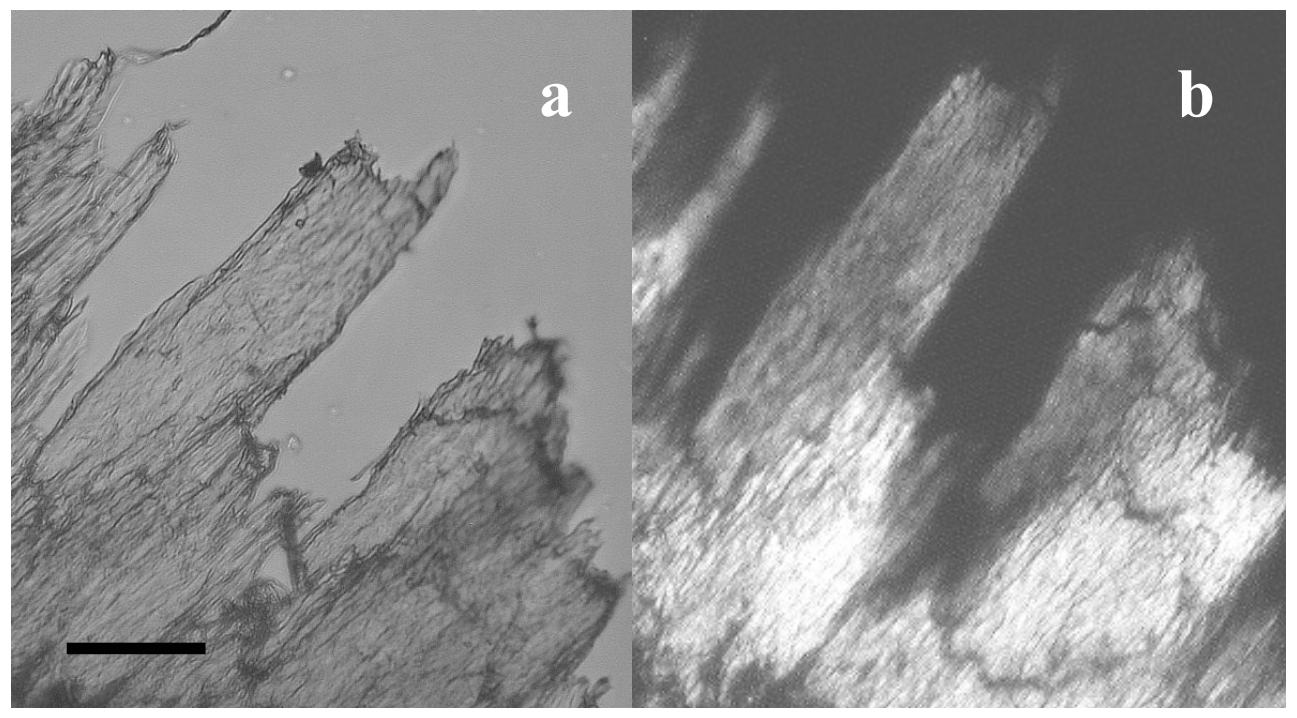

In thin section (cut approximately parallel to the plate) it is possible to observe crystals of palygorskite of several hundred micrometres. The palygorskite from LVC is colourless, presents low relief and its birefringence is low. Polarisation colours are between grey and yellow of first order. The extinction is almost straight. It is a biaxial negative mineral and the elongation is positive (with respect to the exfoliation traces parallel to [001] direction). We can consider two possibilities: they are either a) large crystals with exfoliation traces or b) numerous small crystals, well ordered, and in optical continuity.

SEM micrographs of fracture surfaces confirm that samples are composed of very long fibres placed in a parallel arrangement with a rigid appearance. These fibres are connected forming smooth surfaces (Fig. 3a). It is very difficult to know the average length of the fibres because they are joined together forming closed surfaces. It is only possible to confirm that they are more than ten micrometres in length. When the samples are broken, the fibres separate forming groups or cylindrical rods of an average of $3 \mu \mathrm{m}$ in diameter (Fig. 3a). Only at the edge of the particles, the fibres are disordered (Fig. 3b) and produce ribbons.

Transmission electron micrographs of dispersed samples from LVC palygorskite show the characteristic fibrous morphology of palygorskite, which can be described as bundles of laths. Their size depends on the breaking that takes place during dispersion, but it is possible to see aggregates of more than $20 \mu \mathrm{m}$ of length (Fig. 4a and 4b). Furthermore, they have a variable width (maximum $1 \mu \mathrm{m}$ ). They are composed of a variable number of laths in parallel arrangement. The aggregates of parallel laths are the equivalent of the aggregates of fibres (rods) observed in the SEM study. These fibres (laths and rods) present sizes that are very large if they are compared with those displayed by other well-described samples in the bibliography. Singer (1981), for the Rift Valley palygorskite, describes fibres of average length of 2-3 $\mu \mathrm{m}$, and diameters between $0.15-0.5 \mu \mathrm{m}$. Galán et al. (1975) describe fibres from the Cáceres palygorskite which have average of $2 \mu \mathrm{m}$ in length, varying from 0.5 to $4.5 \mu \mathrm{m}$, and the width or thickness of the fibres varies between $150 \AA$
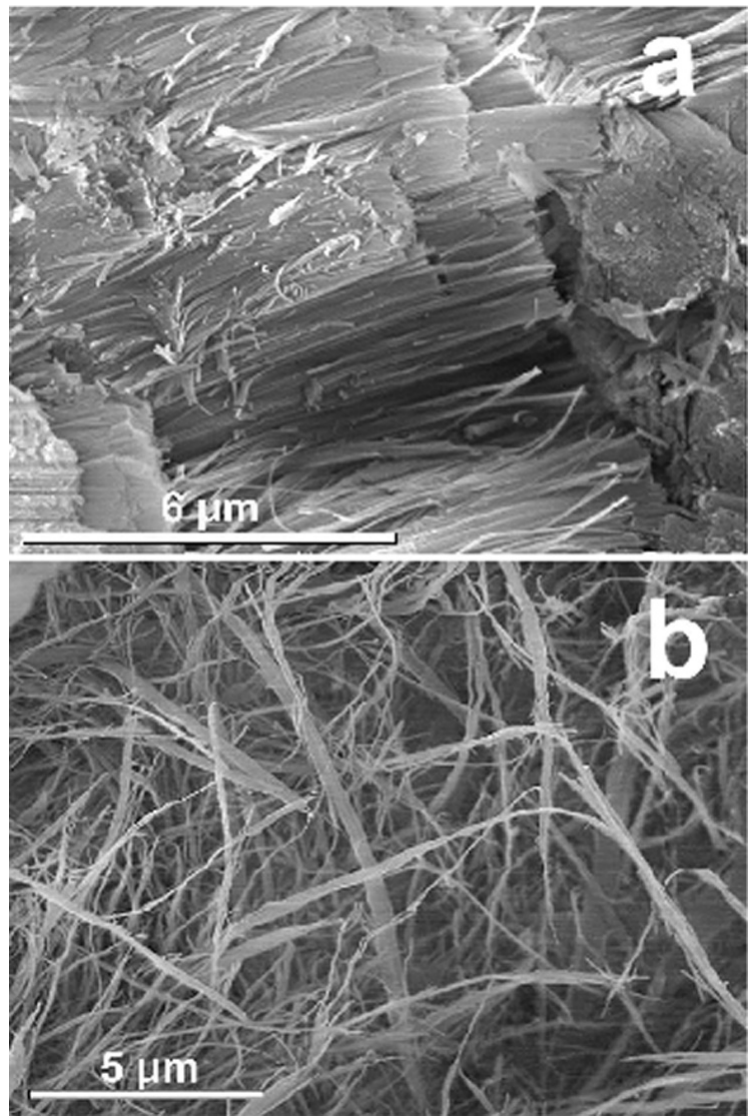

Fig. 3. SEM images. a) Fibres of palygorskite with a rigid appearance forming smooth surfaces. The fibres are placed in parallel arrangement forming cylindrical rods. b) Disordered arrangement of fibres at the edge of plates, forming ribbons.

and $300 \AA$ A. Neaman \& Singer (2000) studied the rheology of aqueous suspensions of palygorskite (from Attapulgus and Yucatan among others) and found the length of the fibres to be between 0.35 and $1.2 \mu \mathrm{m}$. For Rautureau et al. (1979) the limited development of the fibres is related to the dioctahedral character of this mineral, and the longest fibres are the 

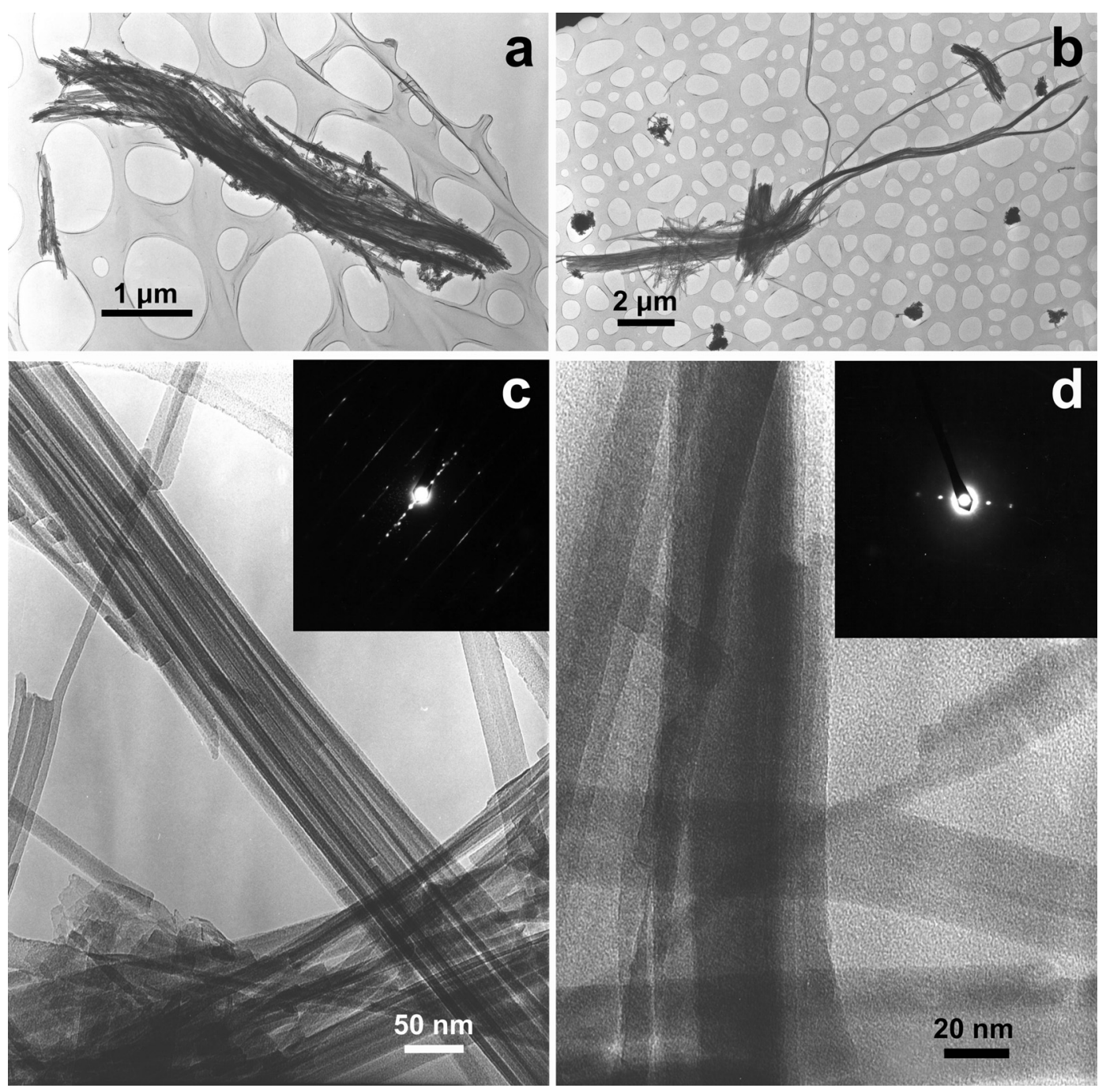

Fig. 4. TEM images. a) and b) A general view of dispersed palygorskite samples (exceeding 20 $\mu \mathrm{m}$ in length). c) Bundle of palygorskite fibres randomly oriented around the $c$ axis. SAED exhibits reflections ordered in l-layers. d) Isolated laths. SAED exhibits spots at 6.3 and $3.15 \AA$ corresponding to 200 and 400 crystal lattice planes.

result of the aggregation of elementary fibres of 50-200 $\AA$. This division between elementary fibres and aggregates of fibres is also made by Singer (1981) who emphasises the different terminology used to describe this mineral. The term fibre is used both for elementary fibres and for fibre aggregates, and the same occurs with the terms lath and rod that sometime are used for fibres and sometime for bundles.

There are several references for palygorskite with very long fibres. Vernet (1967) found palygorskite as filling of a fissure of several tens of micrometres in length. Tien (1973) in his description of the palygorskite from Leicesterhire (UK) mentions fibres with the long axis ranging from 60$120 \mu \mathrm{m}$, as the filling material of a joint in dioritic rocks. Haji-Vassilou \& Puffer (1975) described a macrocrystalline palygorskite (several millimetres in length) associated with calcite in hydrothermal veins and they attributed the macrocrystalline character to recrystallization during an episode of mild deformation. Also Kamineni et al. (1993) found palygorskite-filled fractures as an alteration product of epidote in the Eye-Dashwa Lakes pluton and the fibres ranging in length from 3 to $50 \mu \mathrm{m}$.

In contrast to the above described vein-filling type, the sedimentary palygorskite is much smaller in size. López
Galindo \& Sánchez Navas (1989) arrived at the same conclusion for sepiolite when studying samples from different localities and origins, hydrothermal and sedimentary.

\section{Crystallochemical characterisation}

Figure 5 shows XRD pattern for palygorskite. Also XRD pattern of Yucatan palygorskite (one of the samples used as reference) is plotted for comparison. In both cases only the diffraction maxima of palygorskite are observed, testifying for the purity of samples. In the diffractogram corresponding to LVC sample the diffraction maxima are broader. The most intense 110 has lattice-planes spacing of $10.5 \AA$. The 200 and 040 reflections have d-values of $6.32 \AA$ and $4.46 \AA$, respectively. From them $b_{0}$ is estimated to be about $17.84 \AA$ and $a_{0}$ or $a_{0} \sin \beta$ is $12.64 \AA$. Chisholm $(1990,1992)$ provided the first accurate powder diffraction data in two comparative studies of several samples. These studies served as a basis for further studies carried out by Artioli \& Galli (1994) Artioli et al. (1994), Chiari et al. (2003) and Giustetto \& Chiari (2004). These authors agree that natural palygorskite is formed by a mixture of monoclinic and orthorhombic 


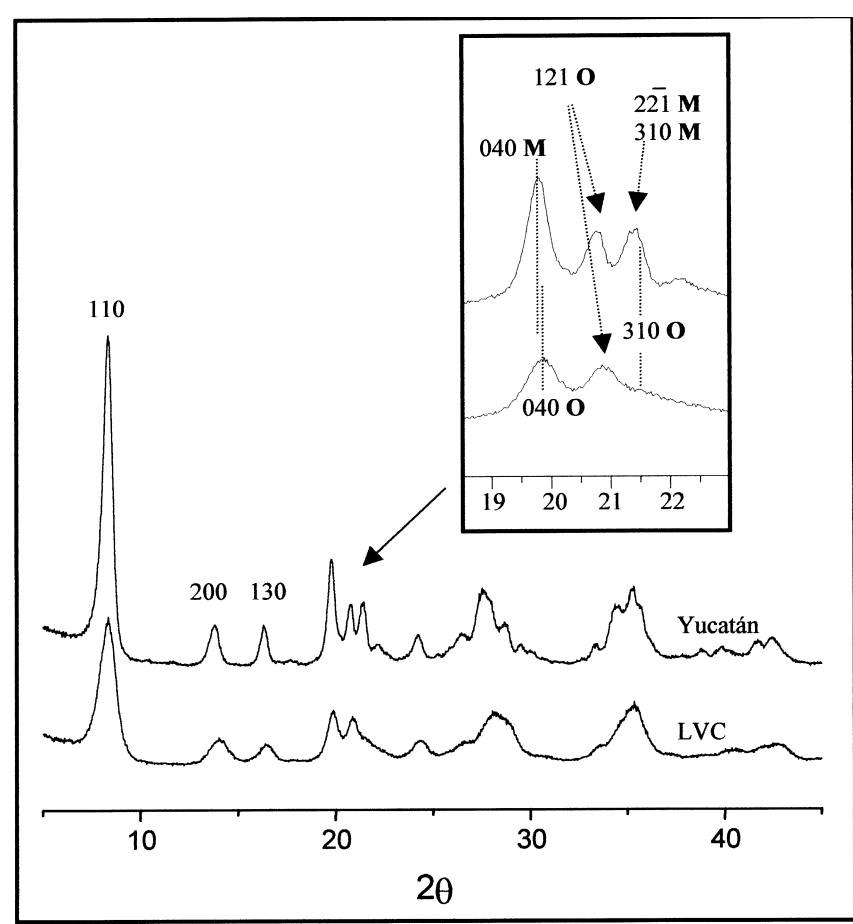

Fig. 5. X-ray diffractograms of powder samples of palygorskites from Yucatan and LVC. Symbols describe the variants (M: monoclinic and O: orthorhombic) with the corresponding Miller indices.

forms and that the variations among different samples of palygorskite can be accounted for by varying proportions of the two forms. The ratio of the contents of orthorhombic and monoclinic palygorskite varies according to the location in which the clay is found (Chiari et al., 2003). The above mentioned authors discuss the differences of intensities of the peaks that appear near $20^{\circ} 2 \theta$ and $35^{\circ} 2 \theta$, and deduce from them the proportions of orthorhombic and monoclinic polytypes.

A study of the Chisholm's first diagnostic region (between $19-23^{\circ} 2$ theta) can be made in spite of the width of the peaks of the sample studied. It can be seen in Fig. 5 that the Yucatan sample contains four peaks in this region, whereas in LVC there are only three, the third appearing as a shoulder. Comparing the patterns obtained with those calculated both by Chisholm (1992) and Arttioli \& Galli (1994) in this region, it can be concluded that the palygorskite from LVC is dominated by the orthorhombic phase. As can be seen in Fig. 5 the LVC sample does not have the 221 and 112 reflections which correspond to the monoclinic phase, while those which correspond to the orthorhombic one 121 and 310 are present with the expected relative intensities $\left(\mathrm{I}_{121} /\right.$ $\mathrm{I}_{310}$ and $\left.\mathrm{I}_{040} / \mathrm{I}_{121}\right)$. The Yucatan sample is very representative and was studied by Chisholm (1990 and 1992) and by Chiari et al. (2003) who found that it is formed by both monoclinic and orthorhombic polymorphs in a proportion of $44 \%$ and $56 \%$ respectively.

The selected area electron diffraction patterns of elongated bundles of fibres exhibit diverse spot patterns, most of them corresponding to polycrystalline patterns. Fig. 4c, shows a bundle of palygorskite fibres randomly orientated around the c axis, showing hk0, hk1, hk2 etc. layers of reflections, and it is possible to calculate the $\mathrm{c}_{0}$ parameter as $5.3 \AA$. This parameter is the same in all different diffraction patterns. In all cases the 001 reflections can be observed only for $1=2 \mathrm{n}$. Only the electron diffraction patterns of isolated laths exhibit monocrystalline patterns. In Fig. 4d, it is possible to detect $6.3 \AA$ and $3.15 \AA$ spacings corresponding to 200 and 400 crystal lattice planes of palygorskite, respectively, and 002 reflections of very low intensity (the latter can not be seen in the figure).

As mentioned above, the optical observations suggest that LVC palygorskite is macrocrystalline. Nevertheless, the electron microscopy shows the macroscopic fibres to be polycrystalline in nature. They can be described as aggregates of parallel thin fibres (tens of nanometers in diameter) variously rotated around the common $\mathrm{c}$ axis. This also explains the broad diffraction maxima observed by XDR.

TEM point analyses (Table 1) of isolated LVC palygorskite particles allow the calculation of their chemical composition. The average chemical formula is:

$\mathrm{Si}_{8.02} \mathrm{O}_{20}\left(\mathrm{Al}_{1.91} \mathrm{Fe}_{0.04} \mathrm{Mg}_{2.01}\right)(\mathrm{OH})_{2}\left(\mathrm{OH}_{2}\right)_{4} \mathrm{Ca}_{0.01} \mathrm{Na}_{0.07}$ $4\left(\mathrm{H}_{2} \mathrm{O}\right)$

which is very close to the idealized formula $\mathrm{Mg}_{2} \mathrm{Al}_{2} \mathrm{Si}_{8} \mathrm{O}_{20}$ $(\mathrm{OH})_{2}\left(\mathrm{OH}_{2}\right)_{4} 4 \mathrm{H}_{2} \mathrm{O}$. It does not show a tetrahedral substitution, the $\mathrm{Mg} / \mathrm{Al}$ rate is close to one, and it has a remarkable low $\mathrm{Fe}^{3+}$ octahedral content. The number of octahedral cations per half unit cell is 3.95 on average. As a consequence, the content of exchangeable cations of LVC palygorskite is very small.

The tetrahedral substitution in natural palygorskites is very low, in general $<0.5$ atoms of $\mathrm{Al}+\mathrm{Fe}^{3+}$ for eight tetrahedral sites (Galán \& Carretero, 1999), but there are few re-

Table 1. Chemical analysis obtained by AEM of isolated LVC palygorskite particles, mean and standard deviation. Number of cations per half unit-cell on the basis of $\mathrm{O}_{20}(\mathrm{OH})_{2}\left(\mathrm{OH}_{2}\right)_{2}$.

\begin{tabular}{lcccccccccccccccc}
\hline & 1 & 2 & 3 & 4 & 5 & 6 & 7 & 8 & 9 & 10 & 11 & 12 & 13 & 14 & Mean & StDes \\
\hline $\mathrm{Si}$ & 8.01 & 8.02 & 8.01 & 7.99 & 7.99 & 8.05 & 8.02 & 8.00 & 8.07 & 8.08 & 8.04 & 8.00 & 8.01 & 7.97 & 8.02 & 0.03 \\
$\mathrm{Al}^{\mathrm{IV}}$ & & & & 0.01 & 0.01 & & & & & & & & & 0.03 & & \\
$\mathrm{Al}^{\mathrm{VI}}$ & 1.93 & 1.91 & 1.89 & 1.89 & 1.91 & 1.94 & 1.91 & 1.93 & 1.83 & 1.82 & 1.85 & 1.89 & 1.98 & 1.99 & 1.91 & 0.04 \\
$\mathrm{Ti}$ & & 0.01 & & & & & & & & & & & & & & \\
$\mathrm{Fe}^{3+}$ & 0.04 & 0.03 & 0.02 & 0.05 & 0.06 & 0.04 & 0.04 & 0.04 & 0.04 & 0.04 & 0.06 & 0.02 & 0.01 & 0.02 & 0.04 & 0.01 \\
$\mathrm{Mg}$ & 1.98 & 2.02 & 2.03 & 2.01 & 2.08 & 1.90 & 1.96 & 2.01 & 1.91 & 2.03 & 2.04 & 2.12 & 1.98 & 2.00 & 2.01 & 0.07 \\
$\Sigma \mathrm{Oc}$. & 3.95 & 3.97 & 3.94 & 3.95 & 4.05 & 3.88 & 3.91 & 3.98 & 3.78 & 3.89 & 3.95 & 4.03 & 3.97 & 4.01 & 3.95 & 0.12 \\
$\mathrm{Ca}$ & & 0.01 & & & & 0.03 & & 0.03 & & 0.02 & & & & & 0.01 & 0.01 \\
$\mathrm{Na}$ & 0.10 & & 0.17 & 0.17 & & & 0.15 & & 0.27 & & & 0.03 & 0.04 & 0.04 & 0.07 & 0.09 \\
\hline
\end{tabular}




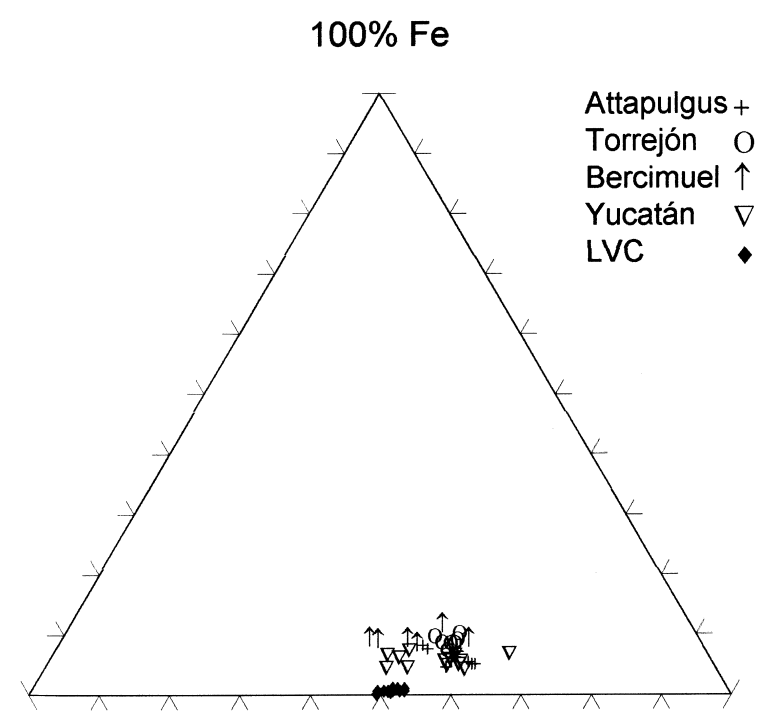

$100 \% \mathrm{Mg}$

$100 \%$ Al

Fig. 6. Ternary diagram for octahedral cations calculated from the AEM analyses of LVC and reference palygorskites (Attapulgus, Bercimuel, Torrejón and Yucatán).

ferences to palygorskite with no tetrahedral substitution as in the case of LVC sample. Tien (1973) found a similar composition for the macroscopic palygorskite from Leicesterhire (UK). If the octahedral occupancies of cations ( $\mathrm{Al}, \mathrm{Mg}$ $\mathrm{Fe}$ ) of the LVC palygorskite are compared to other bibliographic data and reference samples (Attapulgus, Torrejón, Bercimuel and Yucatan) it can be seen that the LVC palygorskite classifies among those with the highest content of Al (Fig. 6). It is possible to affirm that LVC palygorskites present a chemical composition very close to the theoretical composition, with a ratio $\mathrm{Mg} / \mathrm{Al}=1.05$, and without isomorphic substitution of $\mathrm{Al}$ by $\mathrm{Fe}^{3+}$ as is the case in other samples (Newman \& Brown 1987, García-Romero et al., 2004). Moreover, LVC palygorskite has the lowest Fe content of all samples compared (Fig. 6). Galán \& Carretero (1999) affirm that octahedral cations range from 3.45 to 4.33; with $\mathrm{VI}(\mathrm{Al}+\mathrm{Fe})$ between 1.12 and 2.5 for five octahedral sites, and with a $\mathrm{R}^{2+} / \mathrm{R}^{3+}$ ratio close to 1 . The $\mathrm{R}^{2+} / \mathrm{R}^{3+}$ values of LVC palygorskite coincide with the theoretical ratio. The $\mathrm{LVC}$ palygorskite shows a $\mathrm{R}^{2+} / \mathrm{R}^{3+}$ of 1.03 , and 3.95 octahedral cations per half unit cell.

The content of the octahedral layer obtained is similar to that proposed by Galopim de Carvalho et al. (1970) for the palygorskite from LVC. They proposed the structural formula: $\left(\mathrm{Si}_{7.72} \mathrm{Al}_{0.28}\right) \mathrm{O}_{21}\left(\mathrm{Al}_{1.90} \mathrm{Fe}^{3+}{ }_{0.10} \mathrm{Fe}^{2+}{ }_{0.02} \mathrm{Mg}_{1.94} \mathrm{Ti}_{0.02}\right)$ $\left(\mathrm{Ca}_{0.11} \mathrm{~K}_{0.06} \mathrm{Na}_{0.03}\right)$ from chemical analysis of bulk rock.

The FTRI spectrum of the palygorskite from LVC is shown in Fig. 7. It shows differences with respect to bibliographic data that can be explained if we take into account its chemical composition. The assignation of different bands and peaks to the corresponding vibrations is difficult and frequently two or more different interpretations for the same peak are found in the literature. On the other hand, the position of the bands varies when samples from different localities are studied (Frost et al., 1998 and 2001).

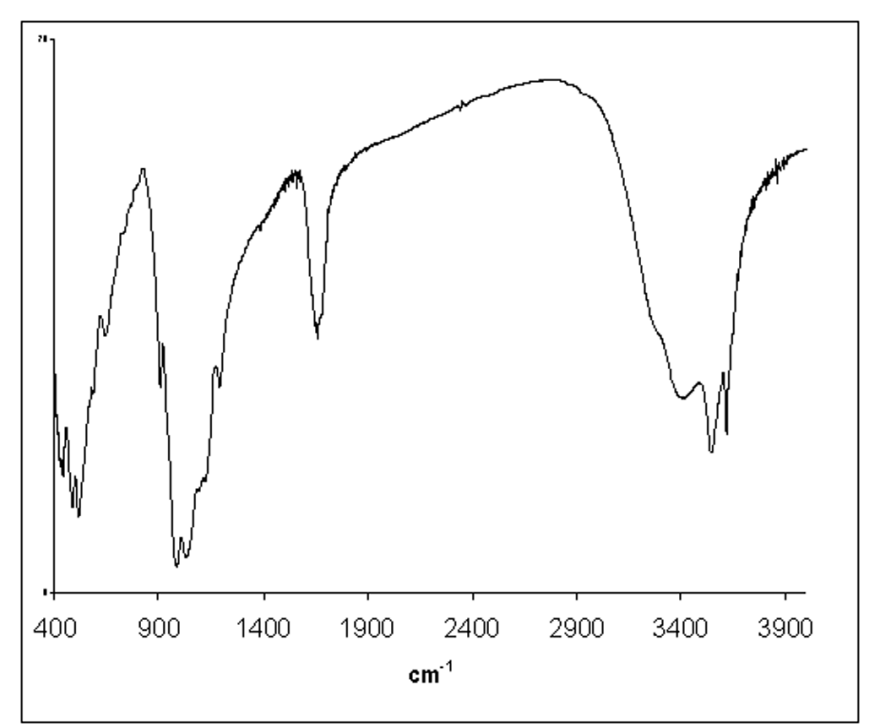

Fig. 7. FTIR spectrum of palygorskite from LVC.

In the region of the highest wavenumber two peaks (at 3614 and $3536 \mathrm{~cm}^{-1}$ ) and a band with a shoulder (3390 and $3270 \mathrm{~cm}^{-1}$, respectively) can be seen in the spectrum of LVC palygorskite. Bands due to vibrations of hydroxyls or water molecules bonded to the octahedral cations (Al, $\mathrm{Mg}$ and $\mathrm{Fe}$ ) (Frost et al., 2001), appear in the region between 3000 and $4000 \mathrm{~cm}^{-1}$. The exact position and the relative intensity of the bands varies in different palygorskites, probably due to the different content of cations in the octahedral layer, but the band at $3614 \mathrm{~cm}^{-1}$, which also appears in the sample studied, seems to be characteristic for this mineral. In the LVC palygorskite this band is very intense and sharp in agreement with the assignation to $\mathrm{O}-\mathrm{H}$ stretching vibration belonging to the coordination sphere of $\mathrm{Al}$, if the important content in octahedral $\mathrm{Al}$ is taken in account.

In the palygorskite studied there is a band at $3536 \mathrm{~cm}^{-1}$. Hayashi et al. (1969) and Mendelovici (1973) establish that the shift of the bands placed at $3550 \mathrm{~cm}^{-1}$ towards $3520 \mathrm{~cm}^{-1}$ upon heating and evacuation is in relation with the lost of coordinated water. We can assume that the band at $3536 \mathrm{~cm}^{-1}$ is due to $\mathrm{OH}_{2}$ bonded to $(\mathrm{Mg}, \mathrm{Al})$. Bearing in mind that the LVC palygorskite has a composition close to the theoretical, it can be assumed that the Al occupies the position M2 of Güven et al. (1992), that is to say the central positions in the octahedral ribbon, whereas the $\mathrm{Mg}$ occupies the external positions, named as M3, as in the structural model proposed by this author for the octahedral layer of palygorskite. Therefore the band at $3536 \mathrm{~cm}^{-1}$ can correspond to $\mathrm{OH}_{2}$ (coordinated water) bonded to $\mathrm{Mg}$. A shoulder placed between 3550 and $3600 \mathrm{~cm}^{-1}$ is frequently described for palygorskite but it does not appear in this sample. This may be due to the fact that only $\mathrm{Al}$ and $\mathrm{Mg}$ are found in octahedral positions and no variation in wavenumber due to $\mathrm{Fe}$ presence is observed. According to Vicente Rodríguez et al. (1996) and Frost et al. (1998), the very broad band at 3390 $\mathrm{cm}^{-1}$ with a shoulder at $3220 \mathrm{~cm}^{-1}$ can be attributed to the hydroxyl stretching frequencies of the water molecules. The broad band of absorption placed at $1660 \mathrm{~cm}^{-1}$ corresponds to absorbed and zeolitic water (bending modes). 
Bands corresponding to $\mathrm{Si}-\mathrm{O}$ can be found in the region of lower wavenumber, close to $1000 \mathrm{~cm}^{-1}$, together with the corresponding $\mathrm{M}-\mathrm{O}$-stretching vibrational bonds and the OH deformation (Frost et al., 2001, Chahi et al., 2002), but this region is very complex due to the overlapping of these and other vibrations (McKeown et al., 2002). The most characteristic peaks in these region for the LVC palygorskite are placed at $1190 \mathrm{~cm}^{-1}$ (attributed by Yariv (1986) to $\mathrm{Si}-\mathrm{O}-\mathrm{Si}$ in alternate ribbons), $910 \mathrm{~cm}^{-1}$ due to deformation of $\mathrm{OH}$ bonded to $\mathrm{Al}$ (Chahi et al., 2003) and the $640 \mathrm{~cm}^{-1}$, which can be related to $\mathrm{Mg}-\mathrm{O}$ bonds (Ausburger et al., 2001 and García-Romero et al., 2004).

Acknowledgments: We would like to express our gratitude to Dr. Silverio Prates and Dr. Isabel Dies for showing the outcrop of LVC palygorskites and we are also very grateful to Dr. Tonèi Baliæ-Øuniæ, Dr. Fernado Nieto and Dr. Cristobal Viedma for their helpful comments. We also express our sincere thanks to Catherine Doyle for checking and improving the English style. Financial support by CICYT (project BTE2002-04017-CO2) is acknowledged.

\section{References}

Artioli, G. \& Galli, E. (1994): The crystal structures of orthorombic and monoclinic palygorskite. Mater. Sci. Forum, 166, 647.

Artioli, G., Galli, E., Burattini, E., Cappuccio, G., Simeoni, S. (1994): Palygorskite from Bolca, Italy: a characterization by high-resolution synchrotron radiation powder diffraction and computerising modelling. N. Jb. Miner. Mh., 1994, 217-229.

Augsburger, M.S., Strasser, E., Perino, E., Mercader, R.C., Pedregosa, J.C. (1998): FTIR and Mössbauer investigation of a substituted palygorskite: silicate with a channel structure. J. Phys. Chem. Sol., 59, 175-180.

Bradley, W.F. (1940). The structural scheme of attapulgite. Am. Mineral., 25, 405-411.

Chahi, A., Petit, S., Decarreau, A. (2002): Infrared evidence of dioctahedral-trioctahedral site occupancy in palygorskite. Clays Clay Miner., 50, 306-313.

Chiari, G., Giustetto, R., Ricchiardi, G. (2003): Crystal structure refinements of palygorskite and Maya Blue from molecular modelling and powder synchrotron diffraction. Eur. J. Mineral., 15, 21-33.

Chisholm, J.E. (1990): An X-ray powder diffractions study of palygorskite. Can. Mineral., 28, 329-339.

-(1992): Powder-diffraction patterns and structural models for palygorskite. Can. Mineral., 30, 61-73.

Choffat, P. (1950): Géologie du cénozoique du portugal. Com. Serv. Geol. Portugal, 30, 182.

Christ, C.L., Hathaway, J.C., Hostetler, P.B., Shepard, A.O. (1969): Palygorskite: new X-ray data. Am. Mineral., 54, 198-205.

Frost, R. L., Cash, G. A., Kloprogge, J. T. (1998): "Rocky Mountain leather" sepiolite and attapulgite - an infrared emission spectroscopy study. Vibrat. Spectr., 16, 173-184.

Frost, R. L., Locos O. B., Ruan, H., Kloprogge, J. T. (2001): Near-infrared and midinfrared spectroscopy study of sepiolites and palygorskites. Vibrat. Spectr., 27, 1-13.

Galán, E. \& Carretero, I. (1999): A new approach to compositional limits for sepiolite and palygorskite. Clays Clay Miner., 47, 399409.
Galán, E., Brell, J. M., La Iglesia, A., Robertson, R. H. S. (1975): The Cáceres palygorskite deposit, Spain. Proc. Intern. Clay Conf. Illinois, 81-94.

Galopim de Carvalho, A., Ubaldo, M.L., Quadrado, R. (1970): Notas de mineralogia e petrografia portuguesas; XV, Paligorsquite do complexo vulcanico de Lisboa. Boletim do Museu e Laboratorio Mineralogico da Faculdade de Ciencias da Universidade de Lisboa, 11-2, 233-239.

García-Romero, E., Suárez Barrios, M., Bustillo Revuelta, M. A. (2004): Characteristics of a Mg-palygorskite in Miocene rocks, Madrid basin (Spain): Clays Clay Miner., 52, 486-496.

Giustetto, R. \& Chiari, G. (2004): Crystal strucutre refinement of palygorskite form neutron powder diffraction. Eur. J. Mineral., 16, 521-532.

Gomes, J. P. (1989): Minerais descobertos em Portugal. Com. Serv. Géol. Portugal, 3, 199-209.

Gouveia, M. A. \& Sequiera Braga, M.A.S. (1995): REE distribution in present day and ancient surface environments of basaltic rocks (Central Portugal). Clay Min., 30, 239- 248

Güven, N., Caillere, J. P. E., Fripiat, J. J. (1992): The coordination of aluminum ions in the palygorskite structure. Clays Clay Miner., 40, 457-461.

Haji-Vassilou. A. \& Puffer, J.H. (1975). A macrocristalline attapulgite-palygorskite ocurrence in calcite veins. Am. Mineral., 60, 328-330.

Hayashi, H., Otsuka, R., Imai, N. (1969): Infrared study of sepiolite and palygorskite on heating. Am. Mineral., 54, 1613-1624.

Jones, B. F. \& Galán, E. (1988): Sepiolite and Palygorskite. in Hydrous Phyllosilicates (exclusive of micas) Chapter 16, Ed. S. W. Bailey. Reviews in Mineralogy, 19. Mineralogical Society of America.

Kamineni, D. C., Griffault, L. Y., Kerrich, R. (1993): Palygorskite from fracture zones in the Eye-Dashwa Lakes granitic pluton. Atikokan, Ontario. Can. Mineral., 31, 173-183.

López Galindo, A. \& Sánchez Navas, A. (1989): Criterios Morfológicos, cristalográficos y geoquímicos de diferenciación entre sepiolitas de origen sedimentario e hidrotermal. Bol. Soc. Esp. Miner., 12, 375-384.

McKeown, D.A., Post, J.E., Etz, E.S. (2002): Vibrational analysis of palygorskite and sepiolite. Clays Clay Miner, 50, 667-680.

Mendelovici, E. (1973): Infrared study of attapulgite and $\mathrm{HCl}$ treated attapulgite. Clays Clay Miner., 21, 115-119.

Neaman, A. \& Singer, A. (2000). Rheological properties of suspensions of palygorskite. Soil Sci. Soc. Am. J., 64, 427-436.

Newman, A.C.D. \& Brown, G. (1987). The chemical constitution of clays. in Chemistry of clays and clay minerals, Pp 1-129. Ed. A. C. D. Newman. Monograph 6, Mineralogical Society. London.

Prudencio, M.I., Sequiera Braga, M.A.S., Gouveia, M. A. (1993): REE mobilization, fractionation and precipitation during weathering of basalts. Chemical Geol., 107, 251-254.

Rautureau, M., Clinard, C., Mifsud, A., Caillère. S. (1979): Étude morphologique de la palygorskite par microscopie électronique. 104 Congrès national des Sociétés savantes, Bordeaux, fasc. III. p. 199-212.

Singer, A. (1981): The texture of palygorskite from the Rift Valley, southern Israel. Clay Min., 16, 415-419.

Tien, P.L. (1973): Palygorskite from Warren Quarry, Enderby, Leicestershire, England. Clay Min., 10-1, 27-34.

Vernet, J.P. (1967): Neoformation d'attapulgite dans le bassin molasique suisse. Bull. Group. Française des Argilles, 19-1, 107-113.

Vicente Rodríguez, M.A., Suárez, M., Bañares, M. A., López González, J. de D. (1996): Comparative FTIR study of the removal of 
octahedral cations and structural modifications during acid treatment of several silicates. Spectr. Acta (A), 52, 1685-1694.

Yariv, S. (1986): Infrared evidence for the occurrence of $\mathrm{SiO}$ groups with double-bond character in antigorite, sepiolite and palygorskite. Clay Min., 21, 923-936.
Received 16 September 2004

Modified version received 10 March 2005

Accepted 19 September 2005 